FULL RESEARCH ARTICLE

\title{
Conflict, coexistence, or both? Cougar habitat selection, prey composition, and mortality in a multiple-use landscape
}

\author{
DAVID C. STONER, ${ }^{1 *}$ MARK A. DITMER ${ }^{2}$, DUSTIN L. MITCHELL ${ }^{1,3}$, \\ JULIE K. YOUNG ${ }^{1,4}$, AND MICHAEL L. WOLFE ${ }^{1+}$
}

${ }^{1}$ Department of Wildland Resources, Utah State University, 5230 Old Main Hill, Logan, UT 84322-5230, USA

${ }^{2}$ USDA Forest Service, Rocky Mountain Research Station, 324 25th Street, Ogden, UT 84401, USA

${ }^{3}$ Utah Division of Wildlife Resources, 319 N Carbonville Rd, Suite A, Price, UT 84501, USA

${ }^{4}$ USDA/APHIS/WS National Wildlife Research Center, Millville, UT 84326, USA

${ }^{\dagger}$ Professor Emeritus

*Corresponding Author: david.stoner@usu.edu

Western North America is experiencing remarkable human population growth and land-use change. Irrigation and associated cultivation have led to colonization of urban-wildland interface (UWI) environments by mule deer (Odocoileus hemionus), and consequently, cougars (Puma concolor). In the wake of these changes, human-wildlife conflicts have increased in tandem with questions about long-term species conservation. To address these concerns, we fit 79 cougars with radio-telemetry collars in the Oquirrh Mountains near Salt Lake City, Utah (2002-2010). Our goal was to evaluate variation in cougar habitat selection, diet, and cause-specific mortality in a landscape dominated by urban, military, and industrial activities. We used radio-telemetry data in concert with Resource Selection Functions to address three hypotheses: (1) that cougars would select wildland over UWI land-uses; (2) prey composition would reflect differences in land-use; and (3) mortality would be predominantly human-caused. Cougars largely selected wildland habitats associated with seasonal mule deer presence, but contrary to expectation, they also selected habitats closer to urban and mined areas. Prey composition in the UWI did not differ from wildland habitats. Domestic ungulates represented only $2 \%$ of 540 recovered prey items and were found primarily in wildlands. Native ungulates comprised $>90 \%$ of the total kill, irrespective of season or land-use, suggesting that use of UWI habitats was linked to mule deer presence. Cougar mortality was disproportionately due to natural causes in wildlands, but individuals that died of human causes in UWI habitats 
were more likely to be inexperienced hunters, supporting young kittens, or compromised by physical handicaps. In general, presence of mule deer was the key predictor of cougar habitat use, even in this highly disturbed, anthropogenically altered landscape. As such, management designed to reduce conflict and ensure conservation will need to focus on urban deer, land-use planning, and targeted education campaigns to reduce food subsidies.

Key words: GPS, habitat selection, human-wildlife conflict, mountain lion, predation, Puma concolor, urban deer, urban-wildland-interface, Utah, wildlife management

Land-use change, water appropriation, and species loss are hallmarks of the Anthropocene (Ellis 2015). Human beings have harnessed and redistributed ecosystem productivity to meet rising demands for food production, minerals, housing, and transportation (Imhoff et al. 2004). These patterns have led to the loss, isolation, and fragmentation of wildlife habitats (Radeloff et al. 2005; Leu et al. 2008). Of these, the redistribution of water has had particularly profound effects in the western United States. The proliferation of irrigation agriculture and ornamental landscaping has decoupled primary productivity from climate signals, thereby turning agricultural and urban areas into highly productive habitats in otherwise arid environments (Buyantuyev and Wu 2012; Li et al. 2017). Altered disturbance regimes such as wildfire have further compounded these trends (Roerick et al. 2019). These land-use changes have impacted biodiversity in two important ways. First, through the extirpation of rare or wide-ranging species, and second, by opening opportunities for habitat generalists (McCullough et al. 1997; Baruch-Mordo et al. 2014; Hansen et al. 2020). Both phenomena have led to increased social concerns over species conservation and humanwildlife conflicts (Rodgers and Pienaar 2017).

Ungulates may be attracted to anthropogenic environments seeking forage (Polfus and Krausman 2012; Longshore et al. 2016) or to avoid the energetic cost of navigating deep snow (Parker et al. 1984; Olson et al. 2015). The predictable presence of highly palatable/ nutritious forage can lead to the loss of migratory behavior (McClure et al. 2005; Barker et al. 2019) and colonization of anthropogenic landscapes (Robb et al. 2019). Under these conditions, management efforts have focused on mitigating disease transmission (Farnsworth et al. 2005), wildlife-vehicle collisions (Bissonette et al. 2008), and crop depredation (Anderson et al. 2012). However, there is a growing concern among the public and wildlife managers that the seasonal or annual presence of mule deer (Odocoileus hemionus) and other ungulates in urban areas has the potential to attract large carnivores with implications for human safety and domestic animal depredations.

Human activity presents carnivores with both costs and opportunities. The presence of garbage, big game gut piles, or roadkill can serve as food resources, inadvertently creating highly predictable subsidies to ecosystems of low or variable productivity (Ruth et al. 2003; Baruch-Mordo et al. 2014; Coon et al. 2019). Human altered landscapes offer an abundance of exotic and naïve prey such as domestic animals (pets, livestock). Additionally, these environments attract small mammals that exploit anthropogenic food sources, supporting larger populations that in turn attract mesocarnivores (e.g. racoons, coyotes, skunks, and possums; Hansen et al. 2020). That said, human caused mortality is almost universally cited in studies of carnivores, even in remote or nominally protected areas (Woodroffe and Ginsburg 1998; 
Packer et al. 2009), suggesting that exploitation of these resources carries substantial risks. Moreover, individual tolerance of human activities varies within populations, and among species and (Myers and Young 2018).

Cougars (Puma concolor) are still widely extant across much of western North America, with their occurrence in a given community predicated on the presence of ungulate prey and adequate stalking cover (Pierce and Bleich 2003). The adaptability and ecological success of this predator is evidenced by its resilience following the Pleistocene extinctions (Culver et al. 2000), wide latitudinal distribution, and current expansions into the boreal forests (Jung and Merchant 2005), agricultural lands (Thompson et al. 2009; Gigliotti et al. 2019), deserts (Choate et al. 2018; Dellinger et al. 2018), the eastern USA (LaRue et al. 2012), and urban-wildland interface ecosystems (Coon et al. 2019). However, as largebodied, obligate carnivores, cougars have extensive spatial requirements and occur at low densities (Stoner et al. 2018), making them vulnerable to hunting (Stoner et al. 2006) and habitat fragmentation (Beier 1995). Indeed, relict populations isolated by urban sprawl are those that best exemplify the social dilemma between species conservation and conflict mitigation (Rodgers and Pienaar 2017).

The public attention to wildlife management responses to human safety concerns has led to investigations of cougar habitat use, behavior, and predation in non-wilderness settings (e.g. Kertson et al. 2011; Wilmers et al. 2013; Alldredge et al. 2019) and reactions to anthropogenic landscapes (Knopff et al. 2014; Ditmer et al. 2020). Debate exists on the sensitivity of cougars to non-lethal anthropogenic influences. Preliminary results have demonstrated cougar use of habitats adjacent to major metropolitan areas while exhibiting a general aversion to human activities (Beier et al. 2010). Murphy et al. (1999) hypothesized that cougars may avoid disturbances such as mining, logging, or recreation if these activities are associated with a threatening human presence. The authors conceded, that in the absence of strong negative consequences, cougars may continue to frequent areas of predictable human activity. Ripple and Beschta (2006) further postulated that the mere presence of humans in large numbers, such as tourists in national parks, can render otherwise high-quality habitat unsuitable. Although not supported by field data, these arguments match the general hypothesis of cougar as a wildland obligate. In contrast, reviews by Beier et al. (2010) and Sweanor and Logan (2010), and a growing body of original research (Alldredge et al. 2019; Knopf et al. 2014) present a more nuanced view, suggesting that in near-urban populations, cougars exhibit individualistic responses to human activities even in the face of substantial human-caused mortality.

Redistribution of limiting resources in the wake of urban expansion has resulted in colonization of anthropogenic landscapes by mule deer and other ungulates (Polfus and Krausman 2012), accompanied by increases in cougar depredation of domestic animals, attacks on humans, and errant cougars in highly populated areas (Torres et al. 1996; Mattson et al. 2011). These phenomena have raised questions about cougar behavior in human-altered landscapes, and more importantly, how to manage human-wildlife conflict, while conserving populations impacted by anthropogenic activities. Our goal was to evaluate variation in cougar habitat selection, diet, and mortality with respect to land-use types. To achieve this, we addressed three working hypotheses: (1) cougars would select for wildlands over anthropogenic land-uses; (2) prey composition would reflect land-use; and (3) mortality would be predominantly human-caused. To test these hypotheses, we compiled data on cougar movements, predation events, and cause-specific mortality across a landscape disturbed by a range of anthropogenic activities. 


\section{METHODS}

\section{Study Area}

The Oquirrh-Traverse Mountains form a boot-shaped complex (hereafter the Oquirrhs) in north-central Utah $\left(40.5^{\circ} \mathrm{N}, 112.2^{\circ} \mathrm{W}\right)$ on the eastern edge of the Great Basin (Fig. 1). The ecoregion is defined by basin and range topography, in which mountains form islands of high productivity relative to the surrounding desert basins, and thus constitute the majority of cougar habitat in an area otherwise defined by aridity. The Oquirrhs measure $>950 \mathrm{~km}^{2}$, but fieldwork was focused on $500 \mathrm{~km}^{2}$ encompassing properties owned and managed by the Kennecott Utah Copper Corporation (Rio Tinto Kennecott) and the Utah Army National Guard (Camp Williams). The site is bounded on the north by the Great Salt Lake and on the east by the Salt Lake Valley, which is home to approximately $40 \%$ of the state's population. Approximately $45 \%$ of the range is privately held or closed to the public (mining, military, aerospace). The remaining land is under the jurisdiction of the Bureau of Land Management (BLM). We selected this site because of its proximity to the greater Wasatch Front metropolitan area, the diverse suite of human activities and associated land uses, and the lack of public access.

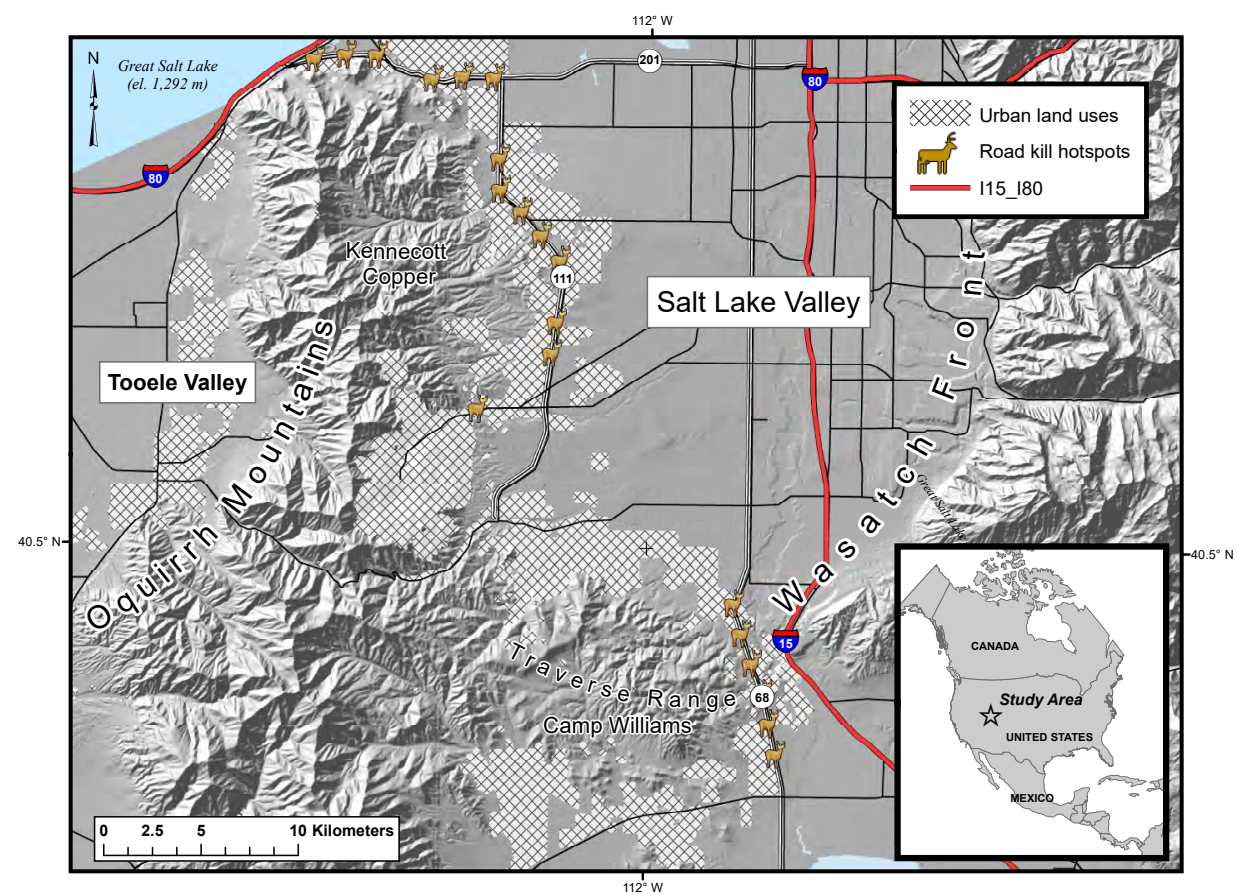

Figure 1. Cougar demography, behavior, and habitat use were studied in the Oquirrh Mountains, Utah from 1997-2010. The site was selected because of its proximity to the Salt Lake City metro area and lack of public access. The site was closed to hunting, but impacted by a wide range of human activities and land uses, including mining, military operations, residential development, and agriculture. The study was initiated in 1997, and GPS technology was introduced in 2002. Hatched area represents the urban-wildland interface (UWI). 
Elevation ranges from 1,292 $\mathrm{m}$ to $3,200 \mathrm{~m}$, and is correlated with variation in moisture, vegetation, and faunal diversity. Annual precipitation ranges from $30-40 \mathrm{~cm}$ in the Salt Lake and Tooele valleys to $100-130 \mathrm{~cm}$ on the highest ridges and peaks. Precipitation is bimodal, with most falling as snow from December-April, followed by a sporadic late summer monsoon. Mean monthly temperatures range from $-2.4^{\circ} \mathrm{C}$ in January to $22.2^{\circ} \mathrm{C}$ in July (Banner et al. 2009). This climatic regimen supports a variety of plant communities. Foothills are dominated by Gambel oak (Quercus gambelii), sagebrush (Artemisia tridentata), and Utah juniper (Juniperus osteosperma). Canyon maple (Acer grandidentatum) is prevalent in riparian zones at low elevations and across broader areas above 1,800 $\mathrm{m}$. Mountain mahogany (Cercocarpus spp.) is common on ridges and well-drained soils. North facing slopes above 2,200 m support localized aspen (Populus tremuloides) and Douglas fir (Pseudotsuga menziesii) forests. Mule deer and elk (Cervus canadensis) are the primary ungulate prey species occupying the site, but a small number of pronghorn antelope ( $\mathrm{An}$ tilocapra americana) and feral horses (Equus caballus) occur on the periphery of the site. Free-ranging livestock, including cattle (Bos taurus), sheep (Ovis aries), goats (Capra hircus), and domestic horses are present from May-December. Potential competitors include coyotes (Canis latrans) and bobcats (Lynx rufus). Historically bighorn sheep (Ovis canadensis) and black bears (Ursus americanus) occurred in the Oquirrhs but were extirpated during the latter $19^{\text {th }}$ century following the introduction of domestic sheep. Both deer and elk are subject to limited annual hunts on the Kennecott portion of the study area. The study site is situated within the Oquirrh-Stansbury Cougar Management Unit, but at the time of the study both properties had been closed to the public and cougar hunting for $>15$ years.

Human activities on the Kennecott property are associated with mineral extraction operations. Attendant infrastructure stretched across $32 \mathrm{~km}$ with large tracts of intact habitat between. Operations included two pits, two concentrators, an in-pit crusher, an ore smelter, evaporation ponds, leach heaps, access roads, slurry and water lines, a tailings impoundment, and office buildings. All operations were continuously active, including 300-ton capacity haul trucks within the mine, various heavy equipment (dozers, front end loaders, track hoes), and light utility trucks. Most operational activities occurred within $200 \mathrm{~m}$ of infrastructure. Camp Williams is operated by the Utah Army National Guard and was used for military training activities. During spring and summer, the camp hosted training battalions of $\geq$ 300 soldiers 4-6 times a year. Up to 8 artillery exercises were held annually. Various small arms ranges were used year-round. These activities resulted in short fire return intervals on parts of the installation (1-5 yrs). Prominent peaks on the site supported commercial radio and television transmitters with associated access roads used year-round. Based on 2010 census data, human densities (residents $/ 100 \mathrm{~km}^{2}$ ) adjacent to the study area varied from 232 in rural Tooele County to 47,259 in urban Salt Lake County (U.S. Census Bureau). The three statistical metro areas that comprise the greater Wasatch Front; Salt Lake City, Provo-Orem, and Ogden-Clearfield, were among the 100 fastest growing American metro areas during 2000-2006.

\section{Capture and Marking}

During winter (December to April) from February 1997 to April 2009 we conducted intensive capture efforts by trailing cougars into trees, culverts, cliffs, or mineshafts using trained hounds. Pursuit, immobilization, and handling procedures were conducted in accordance with Utah State University Institutional Animal Care and Use Committee 
standards (approval no. 937-R), detailed in Stoner et al. (2006). Cougars were aged using the regression models presented in Laundré et al. (2000). We considered animals 1.5-2.5 years to be sub-adults, and those $>2.5$ years as adults. We applied radio collars to all cougars $>40 \mathrm{~kg}$ body mass. We used VHF collars throughout the study (Advanced Telemetry Solutions, Isanti, MN), but beginning in 2002, we annually marked a subset of 3-4 animals with global positioning systems (GPS) collars (Televilt Simplex or LoTek 4400S). These were programmed to acquire 1 fix every 3 hours beginning at midnight, allowing 120 seconds for each fix attempt. This schedule proved the best compromise between battery life (8-13 months) and monitoring circadian movements. Regardless of type, all collars were equipped with an 8-hour mortality sensor. We tracked radio-collared cougars using aerial and ground-based telemetry techniques at approximately monthly intervals. We recaptured GPS instrumented animals annually to download data and replace collar batteries. Data recorded by GPS Collars included a spatial coordinate (Universal Transverse Mercator, zone 12N, WGS 1984); an associated index of position accuracy, date, and time (Mountain Standard Time year-round). Methods for evaluating GPS position accuracy are detailed in Rieth (2009). We analyzed geographic data in ArcMap v. 9.2 (ESRI, Redlands, California).

Circadian and seasonal movements.-All GPS locations were subsampled by time of day and season. We used time tables from the U. S. Naval Observatory (http://www.usno. navy.mil/USNO/astronomical-applications/) to group hours into three categories based on the timing of sunset and sunrise at Salt Lake City during the winter and summer solstices $\left(40.8^{\circ} \mathrm{N}, 111.9^{\circ} \mathrm{W}\right.$, December 21 sunrise: 0748 , sunset: 1702 ; June 22 sunrise: 0456 , sunset: 2002). We considered all points recorded between 0800-1600 hrs diurnal; 2000-0400 hrs nocturnal, and 0500-0700 and 1700-1900 hrs crepuscular. We used a 2-hr window to delineate crepuscular points because of seasonal shifts in photoperiod. Because prey distribution influences cougar behavior and habitat use (Pierce et al. 1999) we defined seasons based on mule deer movement patterns. Median mule deer migration dates in the eastern Great Basin occur in late October and mid-May, reflecting the timing of snow accumulation, melt-off, and plant phenology (McClure et al. 2005). As such, we defined the seasonal calendar as: winter $=$ December-May, summer $=$ June-November (Rieth 2009). Lastly, we used a 30-m digital elevation model (DEM) to quantify seasonal elevation shifts.

Predation events and prey composition.- Spatially, we divided the study area into two categories: near-urban environments constituted the "urban-wildland interface" (UWI), defined here as all anthropogenic land-uses with a 500-m buffer, and "wildlands" (WILD), which constituted all lands $>500 \mathrm{~m}$ from the UWI. Cougars are known to drag carcasses $>$ $400 \mathrm{~m}$ and so the buffer was chosen to adequately capture this behavioral metric (Mondini and Muñoz 2008).

To identify cougar predation events, we used GPS data clusters following the methods detailed by Anderson and Lindzey (2003). GPS coordinates were recorded on internal (storeon-board) collar memory and retrieved upon death, or approximately 1 year after deployment when cougars were recaptured to replace collars. Data points were downloaded into ArcMap to identify, locate, and separate cougar predation events from the data set and produce a map of cougar use locations. This consisted of isolating GPS location clusters comprised of $\geq 2$ points within $100 \mathrm{~m}$ of each other collected between $2000-0400 \mathrm{hrs}$, indicative of a nocturnal feeding session. For fieldwork we assumed a radius of $100 \mathrm{~m}$ around clusters to account for errors induced by variation in canopy cover, terrain, and animal behavior. To calculate the number of days in association with a particular kill, we subtracted the time of 
the first point within $100 \mathrm{~m}$ of the cluster center from the last. All points in between these dates were considered temporally dependent on the cache site. The mean of all GPS locations associated with a cluster location was then programmed into a handheld GPS unit and potential cache site locations were visited to determine if a kill had been made. A search was conducted for approximately 30 minutes, covering a radius of $\leq 100 \mathrm{~m}$ from the mean cluster location.

Prey composition was determined through visual inspection of remains found at putative cache sites. Prey remains were identified to species, sex, and age, when possible, from remaining skull and pelvic characteristics following methods described by Schroeder and Robb (2005). Smaller prey items were identified through skull, dental, foot, and long bone characteristics. Date, duration of use, and site descriptions were recorded for each confirmed cache location, including GPS coordinates (UTM), elevation, slope, aspect, distance to closest game trail, and dominant vegetation species.

Cause-specific mortality.-Causes of cougar mortality were determined through visual inspection and necropsy of carcasses. Common causes of death included hunter harvest, agency removal (depredation), poaching, road kill, intra-specific strife, disease, starvation, and injuries sustained during prey capture. When cause of death could not be determined in the field, the carcass was submitted to the Utah Veterinary Diagnostics Lab for detailed analysis (Wolfe et al. 2015). Date of death was determined using the median date between the last two VHF locations or directly from associated GPS data.

\section{Analytical Techniques}

Resource Selection Functions.-We estimated cougar resource selection functions (RSF) by season and sex (Manly et al. 1992). The RSF model is based on a use-availability design, in which resource values used by an animal (environmental covariates that underlie a telemetry point) are statistically compared to the total availability of those same values within a defined area. This provides an index of the relative likelihood of use given equal availability. We conducted RSF analyses using the cougar cache site data at two scales: 1) the hunting home range (broad scale); and 2) around each individual cache site (fine scale). For the broad scale analysis, we sampled resources within minimum convex polygons (MCP) delineated by the distribution of cache locations for each cougar in winter and summer. Individual MCPs were buffered by $800 \mathrm{~m}$ to account for GPS position errors and animal movements around cache sites. The resultant sampling frame was based on animal use patterns with fitness consequences (i.e. hunting and feeding). For the fine scale RSF, we buffered each cache location by $400 \mathrm{~m}$ (winter) or $330 \mathrm{~m}$ (summer), reflecting mean distances between cache sites and contemporaneous daybeds. For both analyses we generated 'available points' using a random sample with the "spsample" function in the sp package in program R (R Development Core Team 2020; Pebesma and Bivand 2005). For the broad scale analysis, the number of random points within each MCP was based on the size of each cougars' seasonal hunting home range size at a density of 100 random points per $\mathrm{km}^{2}$. For the fine-scale analysis we generated 100 random locations within the buffered areas of each cache site.

Within the RSF framework we evaluated cougar habitat use with respect to seven variables. These included deer habitat, distance to urban areas, distance to mining, distance to agriculture, distance to rural paved roads (i.e. paved roads within the "urban" variable were not included), distance to dirt roads, and shrub habitat. For summer models 'deer 
habitat' was replaced with Normalized Difference Vegetation Index (NDVI). We converted categorical variables to continuous by measuring cougar response in terms of 'distance to'. As such, negative coefficients imply cougar use of habitats that are closer to those features than would be expected by chance. Positive coefficients imply the opposite.

Mule deer are the preferred prey of cougars over much of the West, and as such their presence influences cougar space use (Pierce et al. 1999; Mitchell 2013). Lacking a concurrent sample of marked animals our ability to predict deer presence was limited to the use of an index. We assumed that the presence and abundance of deer during winter would be most predictable on sites with ephemeral snow cover and specific vegetative cover (Parker et al. 1984; Monteith et al. 2011; Fig. 2A). We defined winter deer habitat as southwestern aspects $\left(135^{\circ}-270^{\circ}\right)$ comprised of mountain shrubs and piñon-juniper woodlands with ephemeral snow cover (Robinette et al. 1952). We created a binary "shrub" layer by reclassifying all landcover types within the Southwest ReGAP data (USGS 2004) that included sagebrush, bitterbrush, Gambel oak, or mountain mahogany (Rieth 2009). We used a 30-m digital elevation model to calculate aspect, and overlaid this with the inverse of mean 8-day $500 \mathrm{~m}$ snow cover averaged for each winter season on our site (MOD10A2 v006; Hall and Riggs 2016). The result was a single predictor variable that represented warm aspects (all other slope faces $=0$ ) with increasing values in areas with little or ephemeral winter snow cover. Mean winter snow cover data were assigned the year of the cougar-season cache site data for the broad scale analysis, or the year for winter cache sites in the fine-scale analysis. For summer models we used mean seasonal NDVI, a measure of vegetative greenness, and shrub-dominated habitat as indices of deer habitat. Mean summer NDVI data were collected at 250 m resolution every 16 days (MOD13Q1 v006; Didan 2015) and aligned with contemporaneous cache site data.

We measured several variables representing the human footprint based on anthropogenic land uses that formed an ecotone with native vegetation or terrain. We identified three general sub-categories of human land use and two road types. These were: 1) "urban" (residential, industrial, and commercial buildings and facilities associated with predictable human activity; Fig. 2B), 2) "mining" (lands currently or historically used for open pit mining and associated tailings, leach heaps, and rehabilitated lands), and 3) "agriculture" (all cultivated lands including farms, ranches, pasture, and unirrigated cropland). Other small, localized
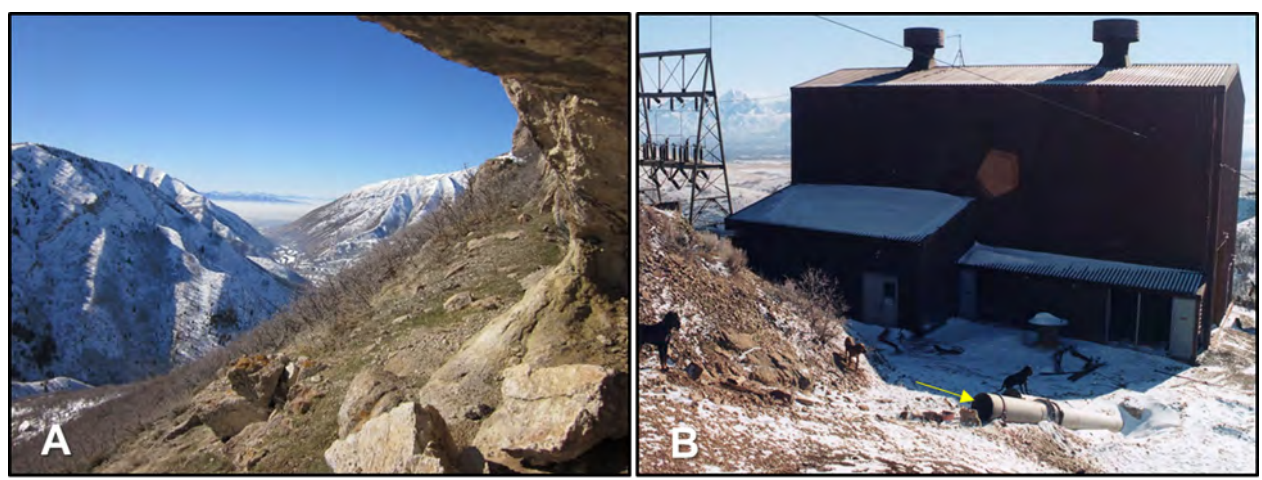

Figure 2. (A) Ephemeral snowpack makes south-facing aspects attractive to mule deer during winter months. (B) Cougars used abandoned buildings such as this mining shed, especially during captures (arrow indicates location of bayed cougar; photos: D. Mitchell and D. Stoner). 
anthropogenic land uses such as disturbed ground, shooting ranges, junkyards, gravel pits, and water tanks were excluded. We used 5-m resolution color digital orthophoto quads collected August 2006 to digitize polygons around each anthropogenic land-use, and then buffered each polygon by $100 \mathrm{~m}$ to account for imagery error (https:/www.usgs.gov/centers/ eros/science/). We used shapefiles delineating the distribution of both dirt and paved roads around the study site (https://gis.utah.gov/\#data). To measure distance, we used the "path distance' function in ArcGIS combined with a 30-m digital elevation model to index cougar response to selected predictor variables. This tool estimates the shortest distance between the edge of a polygon and the neighboring cell, while minimizing variation in elevation. The output was a set of grids in which each cell value represented a distance to the nearest human land-use variable, collectively referred to as the "urban-wildland interface" (UWI).

We used the 'extract' function from the raster package (Hijmans 2020) in program R (R Core Team v.3.13.0) to extract values from the distance-based UWI raster grids and the deer habitat variables for all cache site locations and random points associated with both analyses. For all RSF analyses the response variable was binary, whereby cache sites were given a value of " 1 " and random locations were assigned a value of " 0 ". All RSF models were fit using a weighted likelihood, in which the variable in the "weights" argument was assigned a value of 1000 exponentiated to the power of [ 1 - number of used cache locations] (Muff et al. 2020). For broad-scale analyses we created mixed models, one for each season, that included all five UWI variables, deer habitat variables, and a random intercept for each unique cougar ID. We assessed whether male and female cougars differ in their relationships to various components of the UWI by including an interaction term between sex of the individual and the four human land-use variables that we hypothesized may have the largest effects (distance to: paved road, urban, mining, and agriculture). We used the 'glmer' function in the R package lme4 (Bates et al. 2015) to create summer and winter models. Because our fine scale models assessed how the same set of covariates influenced cache site locations using 330-400m buffers, we took a less conservative modeling approach by assuming each kill and associated cache site were independent (no random effect for ID). Consequently, we used the ' $\mathrm{glm}$ ' function to fit the fine-scale RSF models. Prior to running the models all variables were assessed for high levels of correlation (all pairwise correlations were $<0.7$ so all were retained; Dormann et al. 2013) and each was centered and scaled by the mean and SD for comparative purposes. For both the broad and fine scale seasonal analyses, we fit global models based on a priori hypotheses about cougar cache site selection. Each covariate and interaction within the models were evaluated for significance using 95\% confidence intervals and p-values.

We used our broad scale RSF models to generate seasonal suitability values across the study area without the interactions between sex and human land-use variables. For each cougar, we calculated predicted RSF values by taking the product of the corresponding coefficients from each seasonal model and spatial data (deer habitat, land-use type, roads). We resampled spatial layers with coarse resolutions to $30 \mathrm{~m}$ with a bilinear method. The resulting products for each grid cell were summed and plotted based on the quantile range determined using all predicted RSF values within each seasonal model. Lastly, we subtracted the summer from the winter model to illustrate seasonal changes in cougar resource selection solely on UWI land-uses.

Prey composition.- - To evaluate dietary habits we tallied the number of carcasses of each species detected based on location and compared the proportional occurrence of each prey species with respect to land use, season, and sex (2002-2010). We pooled kills across 
individuals and subdivided them by location (UWI, WILD). We made statistical comparisons for the most common prey species using a chi-square test of equal proportions.

Mortality.-We compared cause and sex-specific mortality between UWI and WILD land-use types. Causes were classified as either 'human' (harvest, poaching, roadkill, and depredation control) or 'natural' (starvation, injury, disease, strife). Statistical comparisons of proportional differences were made using chi-square tests. We then evaluated differences in the age of cougars at the time of death by land-use type using Analysis of Variance. We report descriptive statistics as mean \pm SD unless otherwise noted. All statistical tests were conducted using R software (R Development Core Team 2020).

\section{RESULTS}

\section{Capture and Marking}

From 1997-2009, we marked 79 cougars during 146 capture events. Within this sample, 41 individuals were collared with VHF (21 F, 20 M; 1997-2009), and 24 with GPS instruments (17 F, 7 M; 2002-2009). Fourteen kittens were marked solely with ear tattoos ( $7 \mathrm{~F}, 7 \mathrm{M}$ ). Four additional unmarked cougars were found dead during tracking, including 2 adults $(1 \mathrm{~F}, 1 \mathrm{M}), 1$ subadult female, and 1 male kitten. Mean monitoring time of collared animals ranged from 8-3,286 days ( $\mathrm{F}=926 \pm 895$ days; $\mathrm{M}=564 \pm 476$ days). Three GPS cougars were censored because of early mortality $(1 \mathrm{~F})$ or equipment failure $(2 \mathrm{M})$. Data from the remaining GPS instrumented cougars comprised 1,257 animal-weeks (1,043 F, 214 $\mathrm{M})$, and 38,796 locations. GPS collar acquisition fix success ranged from $19.7-86.1 \%$, and averaged $56.5 \pm 20.9 \%$ for resident females $(n=15)$, and $53.6 \pm 15.7 \%$ for males $(n=5)$. From these data we identified 910 potential cache sites, of which $85 \%$ were field-truthed, resulting in the location of 540 prey items $(\mathrm{UWI}=175$; WILD $=365$ ). The proportion of successful cluster searches was similar between land uses (UWI $=51 \%$; WILD $=56 \%$ ). Habitat selection and prey composition analyses were based solely on GPS collared animals $(\mathrm{n}=21)$, whereas movement and mortality analyses used data from both VHF and GPS collared individuals $(n=42)$.

\section{Circadian and Seasonal Movements}

Cougar elevational use varied both daily and seasonally. Nocturnal positions averaged $65 \mathrm{~m}$ lower than diurnal positions $(1,853 \pm 94 \mathrm{~m}$ vs. 1,918 $\pm 102 \mathrm{~m})$, and were consequently $118 \mathrm{~m}$ closer to human activities at night. This pattern did vary, most notably in that males tended to be closer to the UWI during the day than at night in summer, whereas females displayed the opposite pattern during all seasons. Mean cougar elevational use was 205 $\mathrm{m}$ lower in winter than summer $(1,885 \pm 93 \mathrm{~m}$ vs. $2,090 \pm 193 \mathrm{~m})$, likely a result of snow induced movements by their primary prey. This resulted in a mean lateral shift of $584 \mathrm{~m} \mathrm{(} \pm$ $650 \mathrm{~m}$ ) eastward and therefore closer to the UWI. For the pooled sample mean distance to the UWI was $1,717 \pm 872 \mathrm{~m}$ during summer, decreasing to $1,191 \pm 489 \mathrm{~m}$ in winter.

\section{Hypothesis 1. Cougar Habitat Selection by Land-use Type}

RSF models illuminated notable differences in the way cougars used and reacted to different land-uses (Table 1). At the scale of the home range, indices of deer habitat were significant in both seasons, but several variables associated with the UWI also explained 
Table 1. Model results for cougar resource selection functions at the scale of the hunting home range, by season; Oquirrh Mountains, Utah, 2002-2010.

\begin{tabular}{|c|c|c|c|c|c|}
\hline Season & Variable & Beta estimate & $95 \% \mathrm{CI}$ & Z & $\mathrm{p}$ \\
\hline \multirow[t]{13}{*}{ Winter } & Intercept & -12.59 & $(-13,-12.19)$ & -60.37 & $<0.01$ \\
\hline & Deer Habitat & 0.24 & $(0.15,0.32)$ & 5.49 & $<0.01$ \\
\hline & Dist. Dirt Road & 0.00 & $(-0.13,0.12)$ & 0.00 & 1.00 \\
\hline & SEX: Males & -1.09 & $(-1.92,-0.26)$ & -2.57 & 0.01 \\
\hline & Dist. Paved Road & -0.16 & $(-0.33,0)$ & -1.91 & 0.06 \\
\hline & Dist. Urban & -0.19 & $(-0.36,-0.01)$ & -2.11 & 0.03 \\
\hline & Dist. Mining & -0.43 & $(-0.62,-0.24)$ & -4.40 & $<0.01$ \\
\hline & Dist. Agriculture & 0.39 & $(0.22,0.56)$ & 4.41 & $<0.01$ \\
\hline & Shrub Habitat & 0.19 & $(0.1,0.29)$ & 3.93 & $<0.01$ \\
\hline & SEX:Males X Dist. Paved Road & 0.13 & $(-0.26,0.52)$ & 0.65 & 0.51 \\
\hline & SEX:Males X Urban & 0.11 & $(-0.29,0.5)$ & 0.52 & 0.60 \\
\hline & SEX:Males X Dist. Mining & 0.23 & $(-0.12,0.57)$ & 1.27 & 0.20 \\
\hline & SEX:Males X Dist. Agriculture & -0.72 & $(-1.11,-0.33)$ & -3.63 & $<0.01$ \\
\hline \multirow[t]{13}{*}{ Summer } & Intercept & -12.03 & $(-12.29,-11.77)$ & -89.65 & $<0.01$ \\
\hline & NDVI & 0.57 & $(0.38,0.76)$ & 6.01 & $<0.01$ \\
\hline & Dist. Dirt Road & 0.02 & $(-0.1,0.14)$ & 0.36 & 0.72 \\
\hline & SEX: Males & -1.37 & $(-1.95,-0.79)$ & -4.60 & $<0.01$ \\
\hline & Dist. Paved Road & 0.34 & $(0.16,0.52)$ & 3.65 & $<0.01$ \\
\hline & Dist. Urban & -0.15 & $(-0.3,0.01)$ & -1.89 & 0.06 \\
\hline & Dist. Mining & -0.97 & $(-1.17,-0.76)$ & -9.27 & $<0.01$ \\
\hline & Dist. Agriculture & 0.25 & $(0.08,0.43)$ & 2.81 & $<0.01$ \\
\hline & Shrub Habitat & 0.38 & $(0.26,0.51)$ & 6.21 & $<0.01$ \\
\hline & SEX:Males X Dist. Paved Road & -0.48 & $(-0.92,-0.04)$ & -2.15 & 0.03 \\
\hline & SEX:Males X Urban & 0.36 & $(-0.03,0.76)$ & 1.79 & 0.07 \\
\hline & SEX:Males X Dist. Mining & 0.61 & $(0.2,1.01)$ & 2.95 & $<0.01$ \\
\hline & SEX:Males X Dist. Agriculture & -0.37 & $(-0.74,-0.01)$ & -2.00 & 0.05 \\
\hline
\end{tabular}

cougar habitat use. In general, females showed stronger responses to human land-use variables than males. Mined areas were strongly selected for by females during both seasons, but males only selected for this land use type during summer. Females used habitats closer to urban areas in both seasons, although the relationship was only marginally significant during summer $(p=0.06)$. Males did not show selection for or against these areas. In summer, females strongly avoided paved roads, but males weakly selected for them. Female cougars avoided agriculture year-round, whereas males showed greater tolerance of cultivated land uses relative to females during winter. Cougars demonstrated no discernable reaction to dirt roads in any season. A spatial depiction of model results (sexes pooled) is illustrated in Fig. 3. When viewed in terms of seasonal changes in selection, collectively, cougars increased their use of the UWI by $17 \%$ from summer to winter (Fig. 4). 

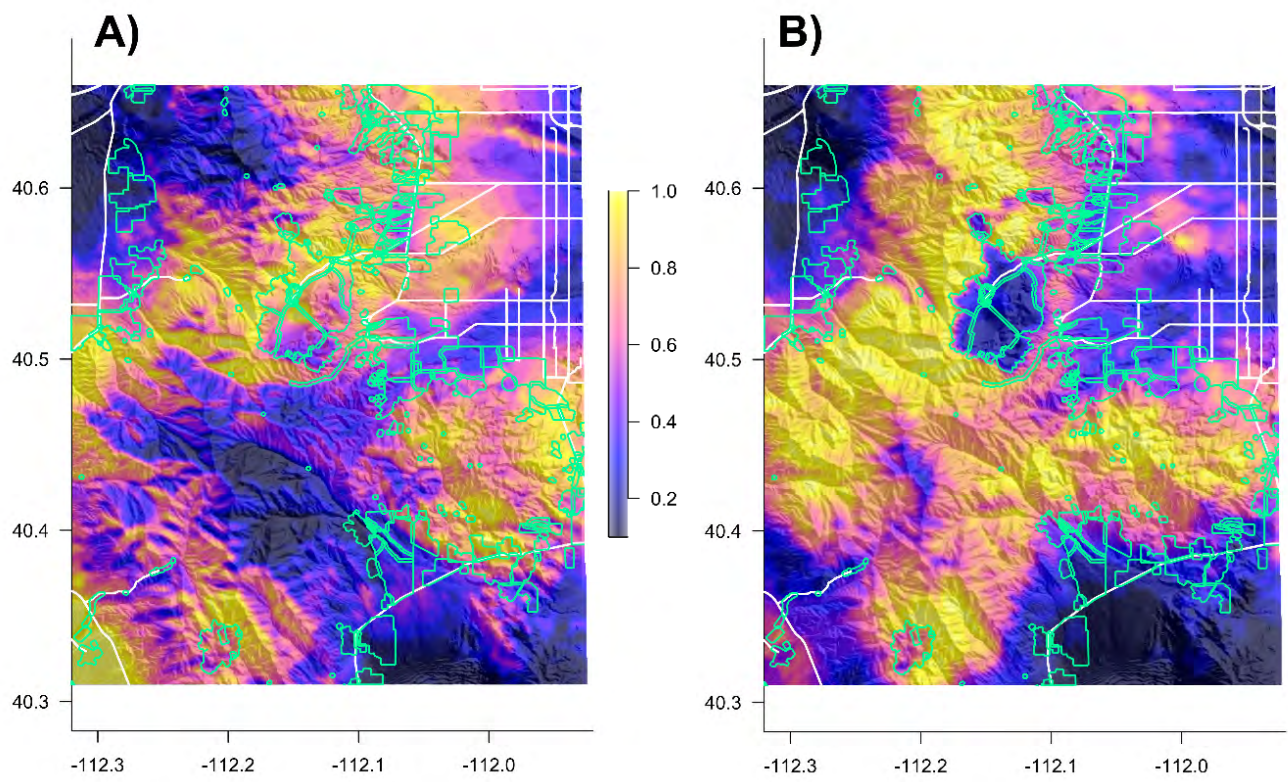

Figure 3. Resource selection functions predicting cougar hunting habitat during (A) winter, and (B) summer in the Oquirrh Mtns, Utah (2002-2010). Areas with the highest probability of use are depicted in yellow, with cooler colors reflecting lower use; white lines are paved roads; green polygons represent anthropogenic land-uses surrounding the study area (urban, mining, agriculture).

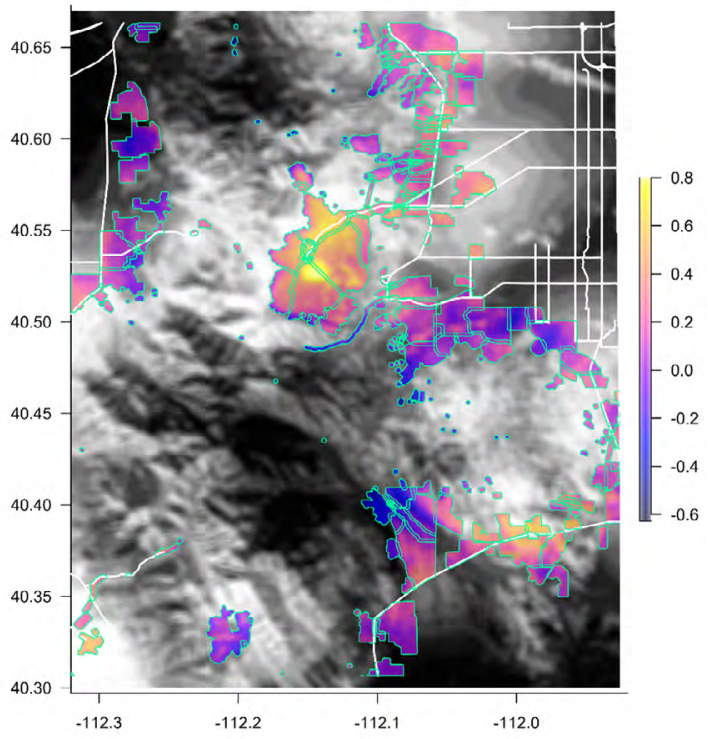

Figure 4. Relative changes in cougar habitat selection between seasons. Predicted resource selection by cougars within urban-wildland interface environments increased by $17 \%$ from summer to winter. Green polygons represent urban-wildland interface environments; warm colors within those polygons indicate relatively higher probability of use by cougars. This approach can be used to identify potential conflict hotspots and prioritize public education campaigns to reduce the availability of food attractants. 
At the scale of the cache site, only variables related to the presence of deer had any influence on model results, i.e. within a 330-400 m radius (summer and winter, respectively) of cache sites, no UWI variables were significant (Table 2).

Table 2. Model results for cougar resource selection functions at the scale of the cache site, by season; Oquirrh Mountains, Utah, 2002-2010.

\begin{tabular}{llccrr}
\hline Season & Variable & Beta estimate & $95 \%$ CI & \multicolumn{1}{c}{ Z } & \multicolumn{1}{c}{$\mathrm{p}$} \\
\hline \multirow{3}{*}{ Winter } & Intercept & -11.53 & $(-11.62,-11.44)$ & -250.95 & $<0.01$ \\
& Deer Habitat & 0.18 & $(0.10,0.27)$ & 4.19 & $<0.01$ \\
& Dist. Dirt Road & 0.01 & $(-0.08,0.11)$ & 0.28 & 0.78 \\
& Dist. Paved Road & -0.01 & $(-0.16,0.14)$ & -0.14 & 0.89 \\
& Dist. Urban & -0.01 & $(-0.17,0.15)$ & -0.11 & 0.91 \\
& Dist. Mining & 0.01 & $(-0.11,0.13)$ & 0.14 & 0.89 \\
& Dist. Agriculture & -0.03 & $(-0.15,0.09)$ & -0.50 & 0.61 \\
& Shrub Habitat & 0.12 & $(0.02,0.21)$ & 2.40 & $<0.01$ \\
& & & & & $<0.01$ \\
Summer & Intercept & -11.53 & $(-11.63,-11.44)$ & -241.57 & 0.59 \\
& NDVI & 0.03 & $(-0.09,0.15)$ & 0.54 & 0.78 \\
& Dist. Dirt Road & 0.02 & $(-0.09,0.12)$ & 0.28 & 0.87 \\
& Dist. Paved Road & -0.01 & $(-0.14,0.11)$ & -0.17 & 0.93 \\
& Dist. Urban & -0.01 & $(-0.15,0.14)$ & -0.09 & 0.84 \\
& Dist. Mining & -0.02 & $(-0.17,0.14)$ & -0.20 & 0.65 \\
& Dist. Agriculture & -0.03 & $(-0.16,0.10)$ & -0.45 & $<01$ \\
\hline Shrub Habitat & 0.20 & $(0.09,0.31)$ & 3.63 & \\
\hline
\end{tabular}

\section{Hypothesis 2. Prey Composition by Land-use Type}

We detected a total of 17 species in cougar cache sites (Table 3). Mule deer were the most common prey species $(n=463)$, followed by elk $(n=39)$, and coyotes $(n=7)$. Domestic species included cattle $(n=6)$, sheep $(n=4)$ and goats $(n=1)$. Mule deer comprised similar proportions of all species killed in both UWI and WILD settings (87.4\% vs. 84.9\%; $\chi^{2}=0.42, d f=1, p=0.52$; Table 3). Within the UWI kill sample (all species combined), the proportion comprised of mule deer was similar between seasons $\left(86.0 \%\right.$ vs. $90.6 \% ; \chi^{2}$ $=0.33, d f=1, p=0.56)$. However, after controlling for species, a greater proportion of the total deer kill occurred in WILD settings than UWI $\left(66.9 \%\right.$ vs. $33.1 \% ; \chi^{2}=105.1, d f=$ $1, p<0.001)$. Seasonally, more deer were killed during winter than summer, regardless of land-use $\left(62.2 \%\right.$ vs. $37.8 ; \chi^{2}=54.2, d f=1, p<0.001$; Fig. 5). Elk only represented 7.2\% of the total kill, but within this subsample, they were killed predominantly in WILD settings $\left(82.1 \%\right.$ vs. $\left.17.9 \% ; \chi^{2}=29.5, d f=1, p<0.001\right)$. Sample sizes were too small to make comparisons by sex. 
Table 3. Prey remains found in urban-wildland interface (UWI) and wildland (WILD) environments, by species, Oquirrh Mountains, Utah, 2002-2010 ( ${ }^{1}$ species unidentified).

\begin{tabular}{lrrrr}
\hline Species & \multicolumn{4}{c}{ Prey remains by land-use type } \\
& $(\mathrm{n})$ & $\mathrm{UWI}$ & $(\mathrm{n})$ & WILD \\
\hline mule deer & 153 & $87.4 \%$ & 310 & $84.9 \%$ \\
elk & 7 & $4.0 \%$ & 32 & $8.8 \%$ \\
coyote & 4 & $2.3 \%$ & 3 & $0.8 \%$ \\
skunk & 2 & $1.1 \%$ & 0 & $0.0 \%$ \\
turkey & 2 & $1.1 \%$ & 2 & $0.5 \%$ \\
canid & 1 & $0.6 \%$ & 1 & $0.3 \%$ \\
red fox & 1 & $0.6 \%$ & 2 & $0.5 \%$ \\
goat & 1 & $0.6 \%$ & 0 & $0.0 \%$ \\
marmot & 1 & $0.6 \%$ & 0 & $0.0 \%$ \\
porcupine & 1 & $0.6 \%$ & 0 & $0.0 \%$ \\
raccoon & 1 & $0.6 \%$ & 0 & $0.0 \%$ \\
dom. sheep & 1 & $0.6 \%$ & 3 & $0.8 \%$ \\
bobcat & 1 & $0.0 \%$ & 1 & $0.3 \%$ \\
cattle & 0 & $0.0 \%$ & 6 & $1.6 \%$ \\
cougar & 0 & $0.0 \%$ & 3 & $0.8 \%$ \\
lagomorph & 0 & $0.0 \%$ & 1 & $0.3 \%$ \\
raptor & 0 & $0.0 \%$ & 1 & $0.3 \%$ \\
\hline & 0 & & &
\end{tabular}

\section{Hypothesis 3. Cause-specific Mortality by Land-use Type}

Given the proximity of this population to an array of human activities and land-uses, we assumed mortality would be primarily human caused. To evaluate this hypothesis, we pooled all animals for which cause of death could be ascertained $(n=25$ VHF, 14 GPS, 3 unmarked individuals), and made comparisons by cause (human vs. natural), sex (males vs. females), land-use (UWI vs. WILD), and season (winter vs. summer). We documented 42 mortalities, of which 13 were human-caused (Table 4). Proportions of human vs. natural causes differed from parity ( $30.9 \%$ vs. $\left.69.1 \% ; \chi^{2}=5.3, d f=1, p=0.02\right)$, but males were more likely to die of human causes than females $\left(52.9 \%\right.$ vs. $16.1 \% ; \chi^{2}=4.5, d f=1, p=$ $0.03)$. Among land-use types, cougar mortalities occurred disproportionately in WILD environments ( $78.6 \%$ vs. $\left.21.4 \% ; \chi^{2}=12.6, d f=1, p<0.001\right)$. Differences in season were also evident, with $90 \%$ of all deaths taking place during winter; of these $76 \%$ occurred in wildland settings, with $83 \%$ of those were due to natural causes.

Cougar mortalities occurring on the UWI were largely human-caused $(\mathrm{F}=60 \%, \mathrm{M}=$ $100 \%$ ), stemming from roadkill and depredation control. Age structure of animals dying in UWI environments differed by sex. Females were significantly older (11.2 \pm 2 vs. $6.1 \pm 3.5$ yrs; $F=8.8, d f=1, p=0.007$ ), and males were significantly younger than their counterparts that died in wildland settings ( $1.6 \pm 1.1$ vs. $5.4 \pm 1.2 \mathrm{yrs} ; F=25.1, d f=1, p<0.001$; Fig. 6). 


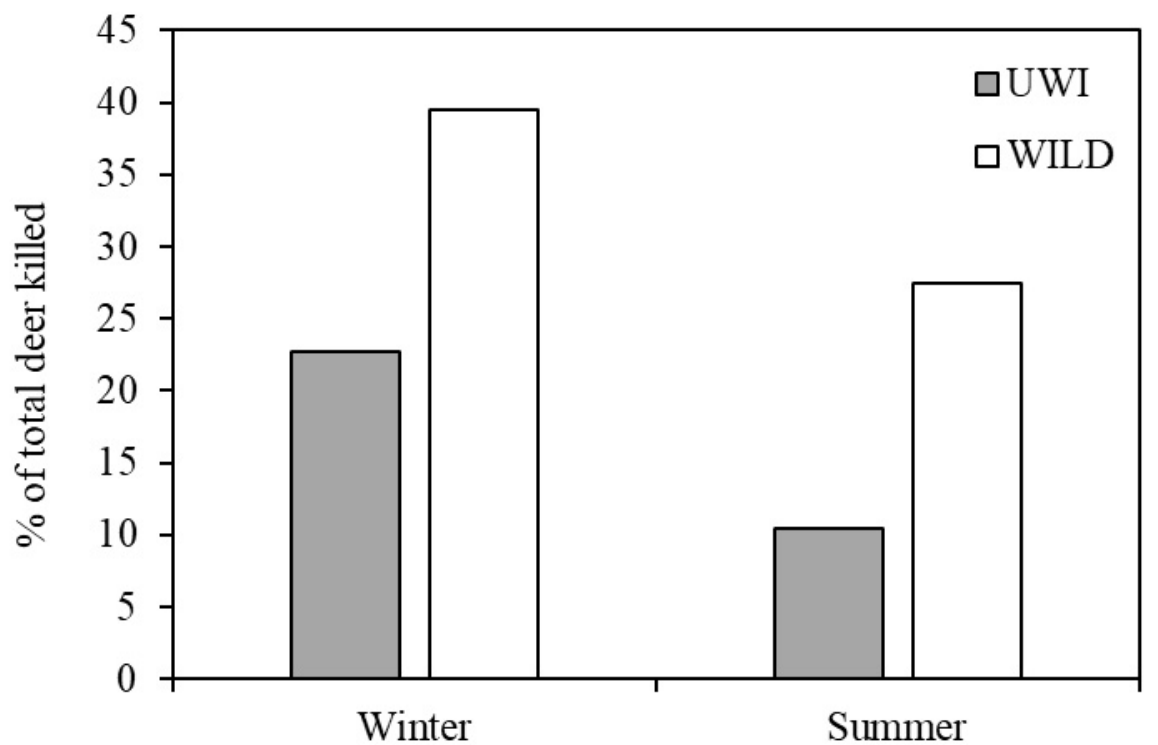

Figure 5. The relative proportions of the total mule deer kill, by season and land-use $(\mathrm{n}=463$; categories sum to $100 \%$ ). More deer were killed in wildland settings during winter than any other season $\times$ land-use combination.

Table 4. Cause-specific cougar mortality by sex, age, season, and land-use $(n=42)$; Oquirrh Mountains, Utah, 2002-2010.

\begin{tabular}{cccccc}
\hline & & & Mortality & \\
Sex & Age & Cause & Type & Season & Land-use \\
\hline F & 10 & roadkill & human & winter & uwi \\
F & 11 & roadkill & human & winter & uwi \\
F & 11 & roadkill & human & winter & uwi \\
F & 6 & poach & human & winter & wild \\
F & 14 & malnutrition & natural & winter & uwi \\
F & 9 & malnutrition & natural & winter & uwi \\
F & 1 & disease & natural & winter & wild \\
F & 2 & strife & natural & spring & wild \\
F & 2 & malnutrition & natural & winter & wild \\
F & 3 & prey & natural & spring & wild \\
F & 3 & strife & natural & winter & wild \\
F & 3 & malnutrition & natural & winter & wild \\
F & 4 & strife & natural & winter & wild \\
F & 5 & strife & natural & winter & wild \\
F & 6 & prey & natural & spring & wild \\
F & 7 & prey & natural & fall & wild \\
F & 7 & malnutrition & natural & winter & wild
\end{tabular}


Table 4 continued.

\begin{tabular}{|c|c|c|c|c|c|}
\hline \multirow[b]{2}{*}{ Sex } & \multicolumn{5}{|c|}{ Mortality } \\
\hline & Age & Cause & Type & Season & Land-use \\
\hline $\mathrm{F}$ & 7 & strife & natural & spring & wild \\
\hline F & 9 & malnutrition & natural & fall & wild \\
\hline $\mathrm{F}$ & 9 & malnutrition & natural & winter & wild \\
\hline $\mathrm{F}$ & 10 & malnutrition & natural & winter & wild \\
\hline $\mathrm{F}$ & 10 & strife & natural & spring & wild \\
\hline $\mathrm{F}$ & 13 & malnutrition & natural & summer & wild \\
\hline $\mathrm{F}$ & 12 & malnutrition & natural & winter & wild \\
\hline F & 3 & strife & natural & winter & wild \\
\hline M & 1 & control & human & winter & uwi \\
\hline M & 1 & roadkill & human & winter & uwi \\
\hline M & 2 & control & human & spring & uwi \\
\hline M & 3 & control & human & winter & uwi \\
\hline M & 4 & harvest & human & winter & wild \\
\hline M & 5 & harvest & human & winter & wild \\
\hline M & 5 & harvest & human & winter & wild \\
\hline M & 6 & harvest & human & fall & wild \\
\hline M & 6 & harvest & human & winter & wild \\
\hline M & 4 & strife & natural & winter & wild \\
\hline M & 4 & strife & natural & spring & wild \\
\hline M & 5 & prey & natural & spring & wild \\
\hline M & 6 & prey & natural & spring & wild \\
\hline M & 7 & strife & natural & winter & wild \\
\hline M & 7 & prey & natural & spring & wild \\
\hline M & 3 & strife & natural & winter & wild \\
\hline M & na & malnutrition & natural & spring & wild \\
\hline
\end{tabular}

\section{DISCUSSION}

\section{Cougar Habitat Selection by Land-use Type}

Western ecosystems are bounded by climatic extremes of drought and heavy snowpack, which affect ungulate movement, habitat use, and population trends. As predicted, cougar behavior mirrored that of their major prey (Pierce et al. 1999). In the anthropogenically altered environments of the Oquirrh Mountains, cougars displayed the strongest associations with habitats that provided hunting advantages or the predictable presence of mule deer (Coon et al. 2019; Ditmer et al. 2020). These patterns were not limited to wildland environments, however, and human-land-uses that mimicked ambush habitat, such as mined areas were readily integrated as habitat. Although we found no evidence of resident cougars systematically traveling through, or foraging directly in urban settings, they did use the UWI, particularly 


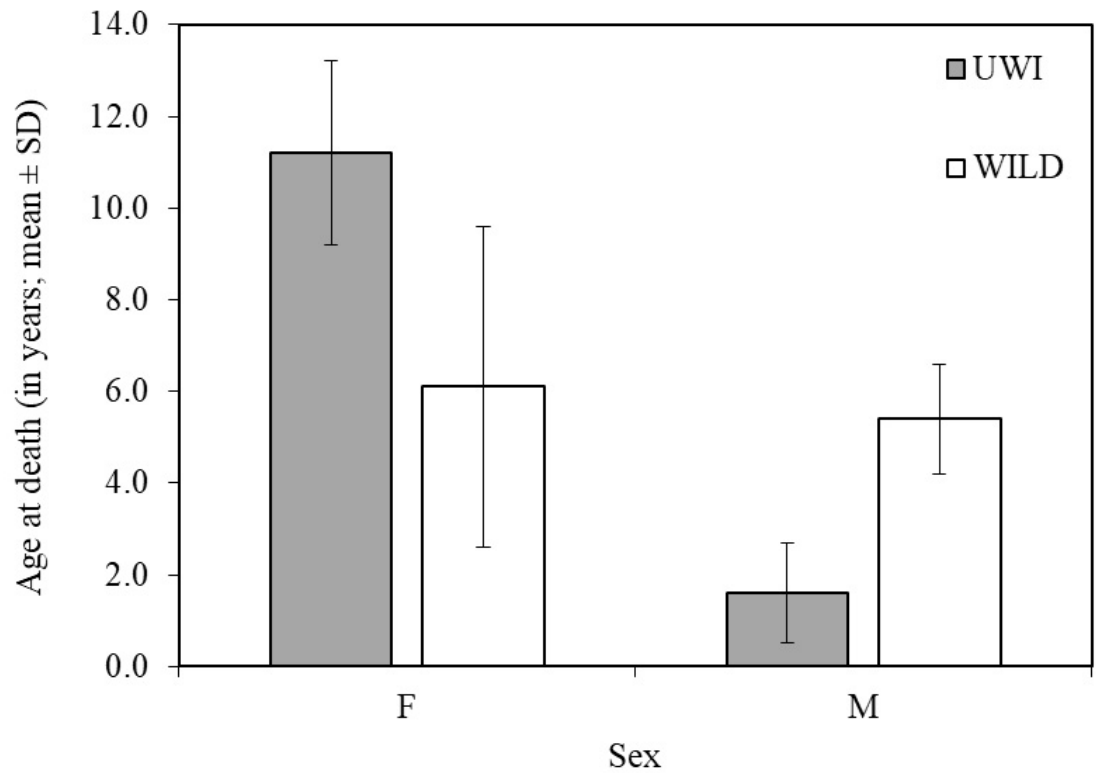

Figure 6. Mean age at time of death $( \pm$ SD) for female and male cougars in UWI and WILD environments. Females dying of any cause on the UWI were significantly older than those dying in wildlands $(n=5)$, whereas among males, animals dying on the UWI were significantly younger than those dying in wildlands $(n=4)$. Males $(n=$ $13)$ and females $(n=20)$ dying in wildland environments did not differ in age.

in winter, when deer occupied low elevation ranges, suggesting that despite human activity, these environments had some foraging value to cougars.

The strong attraction to mined areas has two potential explanations. First, mining and associated reclamation activities most closely approximate the habitat features that cougars seek for hunting (Rieth 2009). The juxtaposition of steep slopes with abrupt ecotones supporting early successional plant communities attracts ungulate prey. Indeed, the use of mined landscapes by three of the most important ungulate prey for cougars has been widely reported, and suggests that rehabilitated sites away from active excavation can be important habitat for mountain ungulates (Olsson et al. 2007; Bleich et al. 2009; Blum et al. 2015). Second, the use of mined areas may indicate presence of an abundant, energetically rewarding alternative prey species, such as marmots (Marmota flaviventris: e.g., Branch et al. 1996). These explanations are not mutually exclusive, but the association with this landscape feature was most pronounced among females during both seasons.

Seasonal use of urban and agricultural lands by ungulates is common in the mountain West (McClure et al. 2005; Anderson et al. 2012; Polfus and Krausman 2012), and in our study area these land-uses were bounded by paved roads connecting outlying suburbs to Salt Lake City. We found 10 cache sites within $200 \mathrm{~m}$ of a highway or railroad, and model results indicated that female cougars exhibited weak selection for rural paved roads in winter. These results suggest that cougars had higher hunting success in certain parts of the UWI, or that they exploited other foraging opportunities that did not require extensive search or travel times. Notably, in winter commuter traffic is heaviest during crepuscular hours when deer are most active, resulting in the production of carrion in certain predictable localities (Kassar and Bissonette 2005). At this scale, our predictions that cougars would select for 
WILD over UWI habitats were largely supported, but not the exclusion of other land-uses occupied by their principal prey.

\section{Prey Composition by Land-use Type}

Patterns in prey composition were similar between UWI and WILD settings with some notable exceptions. Despite cougar selection for UWI habitats, domestic animals were poorly represented in our sample. One goat was killed on the UWI, but all free-roaming sheep and cattle were consumed in wildlands. Among native ungulates, elk were disproportionately killed in wildlands, largely reflecting their distribution, but mule deer comprised similar proportions of the observed kill across land uses. Only variables related to deer habitat were significant in RSF models performed at the scale of the cache site (330-400 m buffer). Combined with the dearth of domestic ungulates in both UWI and WILD settings, this suggests that most cougar use of UWI environments was in pursuit of native prey, rather than pets or livestock (Ditmer et al. 2020). By using the UWI, female cougars may have been capitalizing on scavenging opportunities and vulnerable mule deer (Farnsworth et al. 2005; Krumm et al. 2010), avoiding conspecifics (Benson et al. 2016), or making trade-offs related to reproductive state (Bunnefeld et al. 2006). That said, other diet studies have documented extensive use of small prey, human commensals, and domestic species in UWI environments (Kertson et al. 2011; Moss et al. 2016). Unfortunately, our results are not directly comparable to those efforts, as our sampling methods were biased against small prey items (Stiner et al. 2012). We therefore cannot exclude the possibility that cougars were exploiting food resources other than adult deer, such as feral house cats (Felis catus; Wolfe and Stoner, unpublished data) or other mesocarnivores. Given the importance of small to mid-sized prey for females and subadults (Benson et al. 2016; Moss et al. 2016), these results may underestimate the value of non-ungulate prey in UWI environments for certain demographic classes.

\section{Cause-specific Mortality by Land-use Type}

Human impacted landscapes have been identified as carnivore population sinks as a result of conflicts stemming from food attractants in the form of livestock or garbage (Woodroffe and Ginsburg 1998). Our results offer a mixed view of this argument. Consistent with other studies conducted in non-wilderness landscapes (Thompson et al. 2014; Vickers et al. 2015; Moss et al. 2016; Benson et al. 2020), roadkill and depredation control were the most common anthropogenic mortality factors ( $54 \%$ of human-caused deaths), but only accounted for $17 \%$ of all recorded deaths. Similarly, poaching has been documented in nominallyprotected populations (Vickers et al. 2015; Benson et al. 2020), but represented only a minor source of mortality in our sample $(n=1)$. Hunter harvest occurred in this population $(n=5)$, but was limited to public wildlands adjacent to the study site. When viewed demographically, the distribution of human-caused mortality was bi-modal. All males killed on the UWI were subadults, of which one was handicapped, one orphaned, and the other malnourished. Females showed a remarkable pattern, in which those that died in UWI settings succumbed exclusively to malnutrition and vehicle strikes. In stark contrast to males, females ranged in age from 9-14 years, of which at least two had dependent offspring at the time of death.

These causes are likely related. The canine teeth of cougars exhibit breakage and wear with age (Fig. 7), and roadside carcasses have extensive soft tissue damage, making them easier to locate and consume. All cougar-vehicle collisions $(n=4)$ occurred in two distinct locations, each with an underpass that offered more cover than at-grade crossings. Both 

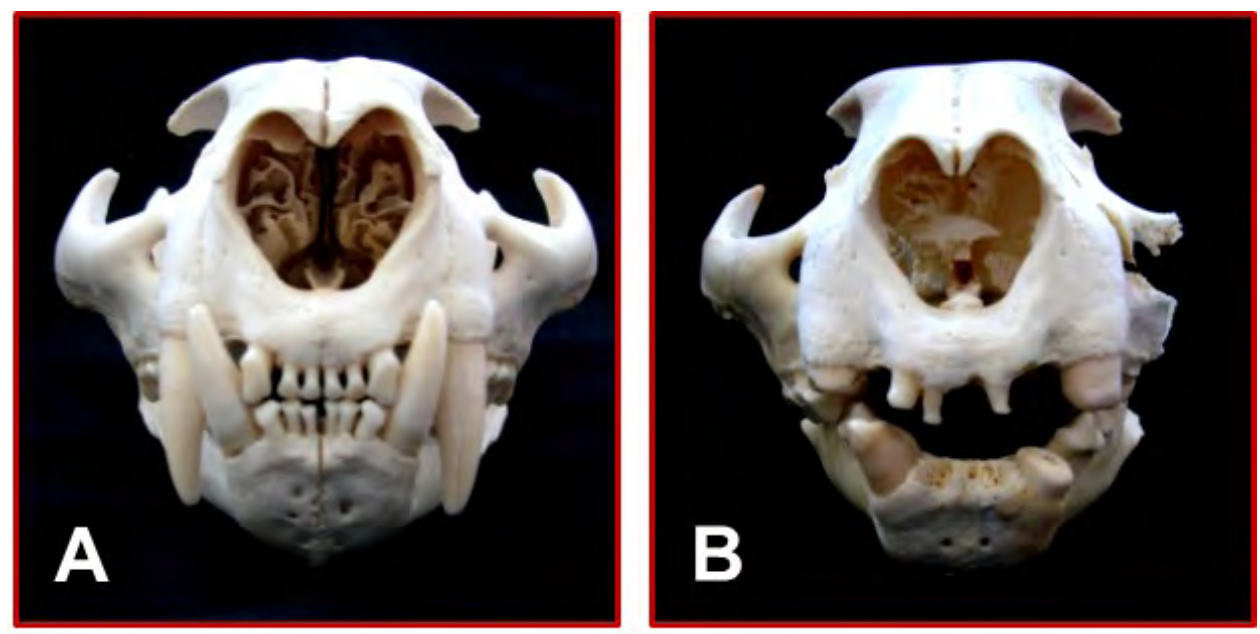

Figure 7. Dental wear may be a factor influencing individual habitat selection and use of anthropogenic food resources in the urban-wildland interface. Note differences in tooth loss, canine breakage, and wear between (A) F51, a 3-yr old that died during prey capture, and (B) F12, a 10-yr old hit by an automobile during early kitten rearing.

sites have been identified as "roadkill hotspots," producing $\geq 1.9$ deer carcasses / km / yr across $18 \mathrm{~km}$ of highway (Kassar and Bissonette 2005; Fig. 1), underscoring the possibility that, rather than simply crossing the highway, these animals were foraging along the roads themselves. We documented such a phenomenon in 2002 when a maternal female made repeated trips over a 13-day interval to feed on road-killed deer in a cemetery adjacent to the study site. The combination of increased energetic demands associated with maternity and extensive dental wear may have motivated these individuals to seek low-risk, manageable prey items most readily available in the form of carrion. Notably, across the study period female survival rates were high (mean $=0.77 \pm 0.05$; Wolfe et al. 2015) and density was constant (Stoner et al. 2006). Thus, despite proximity to one million people, cougars that died on the UWI largely represented compensatory mortality, being inefficient hunters, best exemplified by the very young and the very old.

Our results differ from other studies conducted in UWI settings, in that mortality resulted largely from natural causes, including intraspecific strife, and injuries followed by starvation. Reasons for these discrepancies are speculative, but likely stem from variation in the size and arrangement of the focal UWI environments. For example, in Northern California, Washington, and Colorado, housing was interspersed with forested landscapes, resulting in a more heterogenous mix of land-uses (Kertson et al. 2011; Wilmers et al. 2013; Moss et al. 2016), whereas cougar populations in Southern California are small, isolated, and exhibit hard boundaries with residential housing (Vickers et al. 2015; Benson et al. 2020). In contrast, the Oquirrh site was bounded by flat, open agricultural lands on the east, and steep, unroaded BLM lands on the west, which formed a large buffer around the site effectively increasing the size of the protected area.

\section{Conclusions}

Given the history of conflict between predators and agrarian societies, the ability of a large, potentially dangerous carnivore to persist on the periphery of a major American city 
may seem contradictory. Ecological anomalies and potential threats to this population included commuter traffic, wildfires, persistent habitat loss, and light pollution (Mitchell 2013; Ditmer et al. 2020). Yet within this environment, cougars used vacant buildings, culverts, and mineshafts as den, rest, and cache sites; they hunted native prey near urban areas, scavenged roadkill, and one subadult male successfully dispersed across an 8-lane interstate. Despite their ready availability, domestic ungulates represented only $2 \%$ of recovered kills, and no attacks on humans occurred. Our results add to a growing body of research that attests to the species' ability to navigate heavily disturbed, urban and post-industrial landscapes (Knopff 2014). Thus, contrary to expectations, this population did not fit the profile of an attractive sink or one unduly influenced by edge effects (Woodroffe and Ginsburg 1998, Woodroffe 2000), rather it better approximated the "stability phase" articulated by Linnell et al. (2001), in which regulatory mechanisms, in this case the exclusion of hunting or livestock depredation control on military and industrial properties, allowed this population to persist in the face of high human densities. These findings make it difficult for us to imagine the scenario hypothesized by Ripple and Beschta (2006) in which the predictable presence of humans, unaccompanied by direct lethal consequences, has the capacity to suppress densities or cause abandonment of areas that otherwise exemplify cougar habitat. Indeed, our data suggest just the opposite; that individuals with physical maladies or during certain life stages may exploit foraging opportunities associated with human activities.

\section{Management Implications: Conflict or Coexistence?}

Cougar management is complicated by simultaneous and sometimes incompatible directives focused on minimizing human-wildlife conflict, while conserving populations vulnerable to extirpation. The unique configuration of human land-uses and small area of our site make inference to other UWI cougar populations questionable. That said, trends in urban growth, spatial variation in human-caused mortality, and climate suggest three findings of our work that may be generalizable. First, the strongest predictor of cougar habitat use at all scales was the presence of mule deer. Concurrent work suggests that cougars readily exploit urban deer populations by hunting the dark fringes of the UWI (Ditmer et al. 2020). In drought-prone areas use of irrigated landscapes combined with post-fire plant succession create conditions highly attractive to deer (Roerick et al. 2019). Although urban deer represent one of the most vexing problems faced by state wildlife agencies, reducing this attractant is the single largest variable managers can influence to reduce potential conflict with cougars. Second, in jurisdictions where hunting is either prohibited, such as California, or constrained by land ownership patterns (e.g. Salt Lake City; Stoner et al. 2013), cougars may reach advanced ages not seen in hunted populations. Under these conditions, tooth wear and malnutrition may prompt cougar use of predictable food sources in urban areas. Third, climate predictions for the Southwest indicate a drying trend associated with increased variability in precipitation (Seager et al. 2007). Consequently, drought and heavy winters will continue to shape animal movements in the region. Land-use policies that conserve open space buffers between wildlands and residential areas may afford agency personnel greater latitude for managing deer in mixed-use environments. To increase public support, we suggest development of crowd-sourced, camera-based networks for monitoring trends in species distribution and abundance. When combined with predictive maps of land-use change (e.g. Sexton et al. 2013), the monitoring system could be used to proactively target education campaigns focused on reducing food attractants to deer and other prey species, identify connective habitats, and mapping conflict hotspots (Fig. 4). 


\section{ACKNOWLEDGMENTS}

Primary funding came from the Utah Division of Wildlife Resources (Federal Aid in Wildlife Restoration Program, grant no. W-65-M). Special thanks to the Felidae Conservation Fund for support during the production of this manuscript. We gratefully acknowledge the financial, logistical, and technical contributions of our sponsoring organizations and collaborators; K. Bunnell, C. McLaughlin, T. Becker, A. Aoude, and A. Clark (UDWR); A. Neville and W. Adams from Rio Tinto-Kennecott Copper; and D. Johnson, J. Crane, and R. Dunton from the Utah Army National Guard. Additional financial support was provided by the African Safari Club of Florida, Ecology Center at USU, Utah's Hogle Zoo, American Association of Zoo Keepers, Utah Chapter of the Wildlife Society, Cabellas, Sportsman's Warehouse, and USDA-National Wildlife Research Center. Special thanks to our houndsmen, pilots, and field assistants: M. Mecham, C. Hunt, T. Kogianes, G. Jacobson, L. Redd, K. Shaney, C. Shaffer, C. Hendrix, C. Juran, D. Ranglack, and S. Jochum-Natt. R. Skirpstunas (Utah Veterinary Diagnostic Lab) conducted post-mortem examinations, and S. Durham, W. Rieth, and L. Stoner provided statistical and GIS assistance. We thank V. Monroe for inviting us to participate in this special issue, and three anonymous reviewers for constructive criticism of the original manuscript. We thank P. Roden-Reynolds for productive conversations about urban deer.

\section{LITERATURE CITED}

Alldredge, M. W., F. E. Buderman, and K. A. Blecha. 2019. Cougar-human interactions in the wildland-urban interface of Colorado's front range. Ecology and Evolution 9:10415-10431.

Anderson, C. R., and F. G. Lindzey. 2003. Estimating cougar predation rates from GPS location clusters. Journal of Wildlife Management 67:307-316.

Anderson, E. D., R. A. Long, M. P. Atwood, J. G. Kie, T. R. Thomas, P. Zager, and R. T. Bowyer. 2012. Winter resource selection by female mule deer Odocoileus hemionus: functional response to spatio-temporal changes in habitat. Wildlife Biology 18:153-163.

Banner, R., B. Baldwin, and E. Leydsman-McGinty. 2009. Rangeland resources of Utah. Utah State University Cooperative Extension, USU Press, Logan, UT, USA.

Barker, K. J., M. S. Mitchell, and K. M. Proffitt. 2019. Native forage mediates influence of irrigated agriculture on migratory behaviour of elk. Journal of Animal Ecology 88:1100-1110.

Baruch-Mordo, S., K. R. Wilson, D. L. Lewis, J. Broderick, J. S. Mao, and S. Breck. 2014. Stochasticity in natural forage production affects use of urban areas by black bears: implications to management of human-bear conflicts. PLoS ONE 9(1):e85122.

Bates, D., M. Maechler, B. Bolker, and S. Walker. 2015. Fitting linear mixed-effects models using lme4. Journal of Statistical Software 67(1):1-48.

Beier, P. 1995. Dispersal of juvenile cougars in fragmented habitat. Journal of Wildlife Management 59:228-237.

Beier, P., S. P. D. Riley, and R. M. Sauvajot. 2010. Mountain lions (Puma concolor). Pages 140-155 in S. Gehrt, S. P. D. Riley, and B. L. Cypher, editors. Urban Carnivores: Ecology, Conflict, and Conservation. Johns Hopkins University Press, Baltimore, MD, USA. 
Benson, J. F., J. A. Sikich, and S. P. D. Riley. 2016. Individual and population level resource selection patterns of mountain lions preying on mule deer along an urbanwildland gradient. PLoS ONE 11(7):e0158006.

Benson, J. F., J. A. Sikich, and S. P. D. Riley. 2020. Survival and competing mortality risks of mountain lions in a major metropolitan area. Biological Conservation 241:108294.

Bissonette, J. A., C. A. Kassar, and L. J. Cook. 2008. Assessment of costs associated with deer-vehicle collisions: human death and injury, vehicle damage, and deer loss. Human-Wildlife Conflicts 2(1):17-27.

Bleich, V. C., J. H. Davis, J. P. Marshal, S. G. Torres, and B. J. Gonzales. 2009. Mining activity and habitat use by mountain sheep (Ovis canadensis) European Journal of Wildlife Research 55:183-191.

Blum, M. E., K. M. Stewart, and C. Schroeder. 2015. Effects of large-scale gold mining on migratory behavior of a large herbivore. Ecosphere 6(5):74.

Branch, L. C., M. Pessino, and D. Villarreal. 1996. Response of pumas to a population decline in the plains vizcacha. Journal of Mammalogy 77(4):1132-1140.

Bunnefeld, N., J. D. C. Linnell, J. Odden, M. A. J. van Duijn, and R. Anderson. 2006. Risk taking by the Eurasian lynx (Lynx lynx) in a human dominated landscape: effects of sex and reproductive status. Journal of Zoology, London 270:31-39.

Buyantuyev, A., and J. Wu. 2012. Urban heat islands and landscape heterogeneity: linking spatiotemporal variations in surface temperatures to land-cover and socioeconomic patterns. Landscape Ecology 25(1):17-33.

Choate, D. M., K. M. Longshore, and D. B. Thompson. 2018. Cougar dispersal and natal homing in a desert environment. Western North American Naturalist 78(2):221235.

Coon, A. C., B. C. Nichols, Z. McDonald, and D. C. Stoner. 2019. Effects of land-use change and prey abundance on the body condition of an obligate carnivore at the wildland-urban interface. Landscape and Urban Planning 192:103648.

Culver, M., W. E. Johnson, J. Pecon-Slattery, and S. J. O’Brien. 2000. Genomic ancestry of the American puma (Puma concolor). Journal of Heredity 91:186-197.

Dellinger, J. A., N. W. Darby, and S. G. Torres. 2018. Factors influencing occupancy and detection rates of mountain lions in the Mojave Desert of California. Southwestern Naturalist 63(4):248-255.

Didan, K., MOD13Q1 MODIS/Terra Vegetation Indices 16-Day L3 Global 250m SIN Grid V006. 2015, distributed by NASA EOSDIS Land Processes DAAC. Available from: https://doi.org/10.5067/MODIS/MOD13Q1.006 (Accessed 15 Oct 2020)

Ditmer, M., D. C. Stoner, C. D. Francis, J. R. Barber, J. D. Forester, D. M. Choate, K. E. Ironside, K. M. Longshore, K. R. Hersey, R. T. Larson, B. R. McMillan, D. D. Olson, A. M. Andreasen, J. P. Beckmann, B. P. Holton, T. A. Messmer, and N. Carter. 2020. Artificial night light alters the predator-prey dynamics of an apex carnivore across ecological scales. Ecography 43:1-13.

Dormann, C. F., J. Elith, S. Bacher, C. Buchmann, G. Carl, G. Carré, J. R. G. Marquéz, B. Gruber, B. Lafourcade, P. J. Leitão, T. Münkemüller, C. McClean, P. E. Osborne, B. Reineking, B. Schröder, A. K. Skidmore, D. Zurell, and S. Lautenbach. 2013. Collinearity: a review of methods to deal with it and a simulation study evaluating their performance. Ecography 36:27-46. 
Ellis, E. C. 2015. Ecology in an anthropogenic biosphere. Ecological Monographs 85(3):287-331.

Farnsworth, M. L., L. L. Wolfe, N. T. Hobbs, K. P. Burnham, E. S. Williams, D. M. Theobold, M. M. Conner, and M. W. Miller. 2005. Human land use influences chronic wasting disease prevalence in mule deer. Ecological Applications 15:119-126.

Gigliotti, L. C., M. R. Matchett, D. S. Jachowski. 2019. Mountain lions on the prairie: habitat selection by recolonizing mountain lions at the edge of their range. Restoration Ecology 27(5):1032-1040.

Hall, D. K. and G. A. Riggs. 2016. MODIS/Terra Snow Cover Daily L3 Global 500m SIN Grid, $V$. 6. Boulder, CO., USA. NASA National Snow and Ice Data Center Distributed Active Archive Center. Available from: https://doi.org/10.5067/MODIS/ MOD10A1.006 (Accessed 15 Oct 2020)

Hansen, C. P., A. W. Parsons, R. Kays, and J. J. Millspaugh. 2020. Does use of backyard resources explain the abundance of urban wildlife? Frontiers in Ecology and Evolution 8:570771.

Hijmans, R. J. 2020. raster: Geographic Data Analysis and Modeling. R package version 3.3-13. Available from: https:/CRAN.R-project.org/package=raster

Imhoff, M. L., L. Bounoua, T. Ricketts, C. Loucks, R. Harriss, and W. T. Lawrence. 2004. Global patterns in human consumption of net primary production. Nature 429:870-873.

Jung, T. S., and P. J. Merchant. 2005. First confirmation of cougar, Puma concolor, in the Yukon. Canadian Field-Naturalist 119:580-581.

Kassar, C., and J. A. Bissonette. 2005. Deer-vehicle crash hotspots in Utah: data for effective mitigation. Project Report No. 2005(1):1-128. Utah Cooperative Fish and Wildlife Research Unit, Utah State University, Logan, UT.

Kertson, B. N., R. D. Spencer, and C. E. Grue. 2011. Cougar prey use in a wildland-urban environment in western Washington. Northwestern Naturalist 92:175-185.

Knopff, A. A., K. H. Knopff, M. S. Boyce, and C. C. St. Clair. 2014. Flexible habitat selection by cougars in response to anthropogenic development. Biological Conservation 178:136-145.

Krumm, C. E., M. M. Conner, N. T. Hobbs, D. O. Hunter, and M. W. Miller. 2010. Mountain lions prey selectively on prion-infected mule deer. Biology Letters 6:209-211.

LaRue, M. A., C. K. Nielsen, M. Dowling, K. Miller, B. Wilson, H. Shaw, and C. R. Anderson Jr 2012. Cougars are recolonizing the Midwest: analysis of cougar confirmations during 1990-2008. Journal of Wildlife Management 76:1364-1369.

Laundré, J. W., L. Hernández, D. Streubel, K. Altendorf, and C. López González. 2000. Aging mountain lions using gumline recession. Wildlife Society Bulletin 28(4):963966.

Leu, M., S. E. Hanser, and S. T. Knick. 2008. The human footprint in the West: a largescale analysis of anthropogenic impacts. Ecological Applications 18:1119-1139.

Li, X., Y. Zhou, G. R. Asrar, J. Mao, X. LI, and W. Li. 2017. Response of vegetation phenology to urbanization in the conterminous United States. Global Change Biology 23:2818-2830.

Linnell, J. D. C., J. E. Swenson, and R. Andersen. 2001. Predators and people: conservation of large carnivores is possible at high human densities if management policy is favourable. Animal Conservation 4:345-349. 
Longshore, K. M., C. Lowrey, and P. Cummings. 2016. Foraging at the wildland-urban interface decouples weather as a driver of recruitment for desert bighorn sheep. Wildlife Society Bulletin 40(3):494-499.

Manly, B. F. J. 1992. The Design and Analysis of Research Studies. Cambridge University Press, Cambridge, UK.

Mattson, D., K. Logan, and L. Sweanor. 2011. Factors governing risk of cougar attacks on humans. Human-Wildlife Interactions 5(1):135-158.

McClure, M. F., J. A. Bissonette, and M. R. Conover. 2005. Migratory strategies, fawn recruitment, and winter habitat use by urban and rural mule deer (Odocoileus hemionus). European Journal of Wildlife Research 51:170-177.

McCullough, D. R., K. W. Jennings, N. B. Gates, B. G. Elliott, and J. E. DiDonato. 1997. Overabundant deer populations in California. Wildlife Society Bulletin 25(2):478-483.

Mitchell, D. L. 2013. Cougar predation behavior in north-central Utah. Thesis, Utah State University, Logan, UT, USA.

Mondini, M., and A. S. Muñoz. 2008. Pumas as taphonomic agents: a comparative analysis of actualistic studies in the Neotropics. Quaternary International 180:52-62.

Monteith, K., V. C. Bleich, T. R. Stephenson, B. M. Pierce, M. Conner, R. W. Klaver, and R. T. Bowyer. 2011. Timing of seasonal migration in mule deer: effects of climate, plant phenology, and life-history characteristics. Ecosphere 2(4):art47.

Moss, W. E., M. W. Alldredge, and J. N. Pauli. 2016. Quantifying risk and resource use for a large carnivore in an expanding urban-wildland interface. Journal of Applied Ecology 53:371-378.

Muff, S., J. Signer, and J. Fieberg. 2020. Accounting for individual-specific variation in habitat-selection studies: Efficient estimation of mixed-effects models using Bayesian or frequentist computation. Journal of Animal Ecology 89:80-92.

Murphy, K. M., P. I. Ross, and M. G. Hornocker. 1999. The ecology of anthropogenic influences on cougars. Pages 76-101 in T. W. Clark, A. P. Curlee, S. C. Minta, and P. M. Kareiva, editors. Carnivores in Ecosystems: the Yellowstone Experience. Yale University Press, New Haven, CT, USA.

Myers, P. J., and J. K. Young. 2018. Consistent individual behavior: evidence of personality in black bears. Journal of Ethology 36:117-124.

Olson, D. D., J. A. Bissonette, P. C. Cramer, K. D. Bunnell, D. C. Coster, and P. J. Jackson. 2015. How does variation in winter weather affect deer-vehicle collision rates? Wildlife Biology 21:80-87.

Olsson, P. M. O., J. J. Cox, J. L. Larkin, D. S. Maehr, P. Widen, M. W. Wichrowski. 2007. Movement and activity patterns of translocated elk (Cervus elaphus nelsoni) on an active coal mine in Kentucky. Wildlife Biology in Practice 3(1):1-8.

Packer, C., M. Kosmala, H. S. Cooley, H. Brink, L. Pintea, D. Garshelis, G. Purchase, M. Strauss, A. Swanson, G. Balme, L. Hunter, and K. Nowell. 2009. Sport hunting, predator control and conservation of large carnivores. PLoS ONE 4(6):e5941.

Parker, K. L., C. T. Robbins, and T. A. Hanley. 1984. Energy expenditures for locomotion by mule deer and elk. Journal of Wildlife Management 48:474-488.

Pebesma, E. J., and R. S. Bivand. 2005. Classes and methods for spatial data in R. R News, 5(2), 9-13. Available from https://cran.r-project.org/doc/Rnews/

Pierce, B. M., and V. C. Bleich. 2003. Mountain lion. Pages 744-757 in G. A. Feldhamer, 
B. C. Thompson, and J. A. Chapman, editors. Wild Mammals of North America: Biology, Management, and Conservation. 2nd edition. Johns Hopkins University Press, Baltimore, MD, USA.

Pierce, B. M., V. C. Bleich, J. D. Wehausen, and R. T. Bowyer. 1999. Migratory patterns in mountain lions: implications for social regulation. Journal of Mammalogy 80:986-992.

Polfus, J. L., and P. R. Krausman. 2012. Impacts of residential development on ungulates in the Rocky Mountain West. Wildlife Society Bulletin 36:647-657.

Radeloff, V. C., R. B Hammer, S. I. Stewart, J. S. Fried, S. S. Holcomb, and J. F. McKeefry. 2005. The wildland-urban interface in the United States. Ecological Applications 15:799-805.

Rieth, W. R. 2009. Cougar resource selection in two mountain ranges in Utah: a study on scale and behavior. Thesis, Utah State University, Logan, UT, USA.

Ripple, W. J., and R. L. Beschta. 2006. Linking a cougar decline, trophic cascade, and catastrophic regime shift in Zion National Park. Biological Conservation 133:397408.

Robb, B., Q. Huang, J. O. Sexton, D. Stoner, and P. Leimgruber. 2019. Environmental differences between migratory and resident ungulates: predicting movement strategies in Rocky Mountain mule deer (Odocoileus hemionus) through remotely sensed plant phenology, snow, and land cover. Remote Sensing 11(1980):17.

Robinette, W. L., O. Julander, J. S. Gashwiler, and J. G. Smith. 1952. Winter mortality of mule deer in Utah in relation to range condition. Journal of Wildlife Management 16:289-299.

Rodgers, P. D., and E. F. Pienaar. 2017. Amenity or nuisance? Understanding and managing human-panther conflicts in exurban Florida. Human Dimensions of Wildlife 22(4):295-313.

Roerick, T. M., J. W. Cain, III, and J. V. Gedir. 2019. Forest restoration, wildfire, and habitat selection by female mule deer. Forest Ecology and Management 447:169-179.

Ruth, T. K., D. W. Smith, M. A. Haroldson, P. C. Buotte, C. C. Schwartz, H. B. Quigley, S. Cherry, K. M. Murphy, D. Tyers, and K. Frey. 2003. Large carnivore response to recreational hunting along the Yellowstone National Park and Absaroka-Beartooth Wilderness boundary. Wildlife Society Bulletin 31:1150-1161.

Schroeder M. A., and L. A. Robb. 2005. Criteria for gender and age. Pages 303-338 in C. E. Braun, editor. Techniques for Wildlife Investigations and Management. 6th edition. The Wildlife Society, Bethesda, MD, USA.

Seager, R., M. Ting, I. Held, Y. Kushnir, J. Lu, G. Vecchi, H.-P. Huang, N. Harnik, A. Leetmaa, N.-C. Lau, C. Li, J. Velez, and N. Naik. 2007. Model projections of an imminent transition to a more arid climate in southwestern North America. Science 316(5828):1181-1184.

Sexton, J. O., X. P. Song, C. Huang, S. Channan, M. E. Baker, and J. R. Townshend. 2013. Urban growth of the Washington, D.C.-Baltimore, MD metropolitan region from 1984 to 2010 by annual, Landsat-based estimates of impervious cover. Remote Sensing of Environment 129:42-53.

Stiner, M. C., N. D. Munro, and M. Sanz. 2012. Carcass damage and digested bone from mountain lions (Felis concolor): implications for carcass persistence on landscapes as a function of prey age. Journal of Archaeological Science 39:896-907. 
Stoner, D. C., J. O. Sexton, D. M. Choate, J. Nagol, H. H. Bernales, S. A. Sims, K. E. Ironside, K. M. Longshore, and T. C. Edwards. 2018. Climatically driven changes in primary production propagate through trophic levels. Global Change Biology 24(10):4453-4463

Stoner, D. C., M. L. Wolfe, and D. M. Choate. 2006. Cougar exploitation levels in Utah: implications for demographic structure, population recovery, and metapopulation dynamics. Journal of Wildlife Management 70:1588-1600.

Stoner, D. C., M. L. Wolfe, W. R. Rieth, S. Durham, K. Bunnell, and L. L. Stoner. 2013. De facto refugia, ecological traps, and the biogeography of anthropogenic cougar mortality in Utah. Diversity and Distributions 19(9):1114-1124.

Sweanor, L. L., and K. A. Logan. 2010. Cougar-human interactions. Pages 190-205 in M. Hornocker and S. Negri, editors. Cougar Ecology and Conservation. University of Chicago Press, Chicago, IL, USA.

Thompson, D. J., D. M. Fescke, J. A. Jenks, and A. R. Jarding. 2009. Food habits of recolonizing cougars in the Dakotas: prey obtained from prairie and agricultural habitats. American Midland Naturalist 161:69-75.

Thompson, D. J., J. A. Jenks, and D. M. Fescke. 2014. Prevalence of human-caused mortality in an unhunted cougar population and potential impacts to management. Wildlife Society Bulletin 38:341-347.

Torres, S. G., T. M. Mansfield, J. E. Foley, T. Lupo, and A. Brinkhaus. 1996. Mountain lion and human activity in California: testing speculations. Wildlife Society Bulletin 24:451-460.

U.S. Geological Survey (USGS). 2004. National Gap Analysis Program. Provisional digital land cover map for the southwestern United States. V.1.0. RS/GIS Laboratory. College of Natural Resources, Utah State University, Logan, UT, USA.

Vickers, T. W., J. N. Sanchez, C. K. Johnson, S. A. Morrison, R. Botta, T. Smith, B. S. Cohen, P. R. Huber, H. B. Ernest, and W. M. Boyce. 2015. Survival and mortality of pumas (Puma concolor) in a fragmented, urbanizing landscape. PLoS ONE 10(7):e0131490.

Wilmers, C. Y., Wang, B. Nickel, P. Houghtaling, Y. Shakeri, M. L. Allen, J. KermishWells, V. Yovovich, and T. Williams. 2013. Scale dependent behavioral responses to human development by a large predator, the puma. PLoS ONE 8(4):e60590.

Wolfe, M. L., D. N. Koons, D. C. Stoner, P. Terletzky, E. M. Gese, D. M. Choate, and L. M. Aubry. 2015. Is anthropogenic cougar mortality compensated by changes in natural mortality in Utah? Insight from long-term studies. Biological Conservation 182(1):187-196.

Woodroffe, R. 2000. Predators and people: using human densities to interpret declines in large carnivores. Animal Conservation 3:165-173.

Woodroffe, R., and J. R. Ginsburg. 1998. Edge effects and the extinction of populations inside protected areas. Science 280:2126-2128.

Submitted 31 October 2020

Accepted 30 November 2020

Associate Editor was J. Dellinger 